To be published in

Proceedings of the 12th Annual Conference on Fossil Energy Materials

Knoxville, TN May 12-14, 1998 Department of Energy Rod Judkins, compiler

$$
\begin{gathered}
\text { Fye, } 1178 \\
\text { Fos.l } \\
\text { p.pe- }
\end{gathered}
$$

\title{
ULTRAHIGH TEMPERATURE INTERMETALLIC ALLOYS
}

\author{
M.P. Brady, J.H. Zhu, C.T. Liu, P.F. Tortorelli, J.L. Wright, and C.A. Carmichael \\ Metals and Ceramics Division \\ Oak Ridge National Laboratory \\ Oak Ridge, TN 37831-6115 USA \\ ABSTRACT

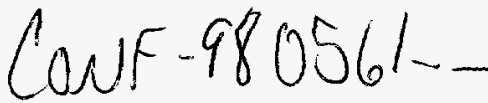

ORNL/CP-99045

\begin{abstract}
A new family of $\mathrm{Cr}-\mathrm{Cr}_{2} \mathrm{Ta}$ intermetallic alloys based on $\mathrm{Cr}-(6-10) \mathrm{Ta}$ (at.\%) is under development for structural use in oxidizing environments in the $1000-1300^{\circ} \mathrm{C}\left(1832-2372^{\circ} \mathrm{F}\right)$ temperature range. Developmental objectives relate to high temperature strength and oxidation resistance and room temperature fracture toughness. The $1200^{\circ} \mathrm{C}\left(2192^{\circ} \mathrm{F}\right)$ strength goals have been met: yield and fracture strengths of $275 \mathrm{MPa}(40 \mathrm{ksi})$ and $345 \mathrm{MPa}(50 \mathrm{ksi})$, respectively, were achieved. Progress in attaining reasonable fracture toughness of $\mathrm{Cr}-\mathrm{Cr}_{2} \mathrm{Ta}$ alloys has been made; current alloys exhibit roomtemperature values of about $10-12 \mathrm{MPa} V_{\mathrm{m}}\left(1.1 \mathrm{MPa} V_{\mathrm{m}}=1 \mathrm{ksi} \sqrt{i n}_{\text {. }}\right)$. Oxidation rates of these alloys at $950^{\circ} \mathrm{C}\left(1742^{\circ} \mathrm{F}\right)$ in air are in the range of those reported for chromia-forming alloys. At $1100^{\circ} \mathrm{C}$ $\left(2012^{\circ} \mathrm{F}\right)$ in air, chromia volatility was significant but, nevertheless, no scale spallation and positive weight gains of $1-5 \mathrm{mg} / \mathrm{cm}^{2}$ have been observed during $120-\mathrm{h}, 6$-cycle oxidation screening tests. These mechanical and oxidative properties represent substantial improvement over $\mathrm{Cr}_{-} \mathrm{Cr}_{2} \mathrm{Nb}$ and $\mathrm{Cr}-\mathrm{Cr} 2 \mathrm{Zr}$ alloys previously developed.
\end{abstract}

\section{INTRODUCTION}

The objective of this work is to develop high-strength, oxidation- and corrosion-resistant intermetallic alloys for use as hot components in advanced fossil energy conversion and combustion systems that meet the $65 \%$ efficiency goal of the Vision 21 Concept. Successful development of these alloys is expected to allow improvement in thermal efficiency primarily through decreased cooling requirements in advanced gas turbines. Initially targeted applications include components such as vanes, seals, and nozzles. However, these materials may also find other uses as wear-resistant parts in coal handling systems (for example nozzles), drill bits for oil/gas wells, valve guides in diesel engines, and interconnects in solid oxide fuel cells.

Development efforts have focused on two-phase, in-situ composite alloys of the type $\mathrm{Cr}-\mathrm{Cr}_{2} \mathrm{X}$, where $\mathrm{Cr}_{2} \mathrm{X}$ is a $\mathrm{Cr}$-based refractory Laves phase compound $\left(\mathrm{Cr}_{2} \mathrm{Nb}, \mathrm{Cr}_{2} \mathrm{Zr}\right.$, or $\left.\mathrm{Cr}_{2} \mathrm{Ta}\right)$. Toughness and oxidation resistance are provided by a soft $\mathrm{Cr}_{\text {ss }}$ (solid solution) matrix. The $\mathrm{Cr}_{2} \mathrm{X}$ Laves phase acts as a reinforcement to the $\mathrm{Cr}_{S S}$ matrix in order to provide high temperature strength. Recently, we identified a promising new class of alloys based on the $\mathrm{Cr}-\mathrm{Cr}_{2} \mathrm{Ta}$ system 1,2 (Fig. 1), with melting points in the 1600 $1700^{\circ} \mathrm{C}\left(2912-3092^{\circ} \mathrm{F}\right)$ range ${ }^{3}$. Preliminary evaluation suggested that the $\mathrm{Cr}-\mathrm{Cr}_{2} \mathrm{Ta}$ based alloys possess superior mechanical properties and oxidation resistance to the $\mathrm{Cr}-\mathrm{Cr}_{2} \mathrm{Nb}$ and $\mathrm{Cr}-\mathrm{Cr}_{2} \mathrm{Zr}$ alloys previously developed in this program ${ }^{3}$. This report presents an overview of current $\mathrm{Cr}_{-}-\mathrm{Cr}_{2} \mathrm{Ta}$ alloy development objectives and performance.

\section{DISCUSSION OF CURRENT ACTIVITIES}

Three properties are key to the initial development of the two phase $\mathrm{Cr}$ - $\mathrm{Cr}_{2} \mathrm{Ta}$ based alloys: room temperature fracture toughness, high temperature strength, and high temperature oxidation resistance. The target mechanical properties are room temperature fracture toughness $\geq 15-20 \mathrm{MPa} V_{\mathrm{m}}\left(1.1 \mathrm{MPa} \sqrt{\mathrm{m}}_{\mathrm{m}}\right.$

The submitted manuscript has been tuthored by a contractor of the U. $\$$. Gousernment under

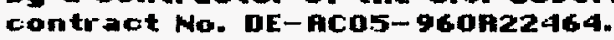

focordingly, the U. f. Goudrnment retains a

nonemclusiug, royalty-frea liownse to publish

or reproduce the published form of this

contribution, or allow others to do $\pm \mathrm{m}$, for

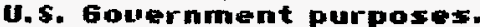

OXRECEEVE'O

AUG 131998

OSTI 


\section{DISCLAIMER}

This report was prepared as an account of work sponsored by an agency of the United States Government. Neither the United States Government nor any agency thereof, nor any of their employees, makes any warranty, express or implied, or assumes any legal liability or responsibility for the accuracy, completeness, or usefulness of any information, apparatus, product, or process disclosed, or represents that its use would not infringe privately owned rights. Reference herein to any specific commercial product, process, or service by trade name, trademark, manufacturer, or otherwise does not necessarily constitute or imply its endorsement, recommendation, or favoring by the United States Government or any agency thereof. The views and opinions of authors expressed herein do not necessarily state or reflect those of the United States Government or any agency thereof. 


\section{DISCLAIMER}

Portions of this document may be illegible in electronic image products. Images are produced from the best available original document. 
range of commercial chromia $\left(\mathrm{Cr}_{2} \mathrm{O}_{3}\right)$ forming alloys is the goal for temperatures up to about 900 $1000^{\circ} \mathrm{C}\left(1652-1832^{\circ} \mathrm{F}\right)$. At higher temperatures, where chromia scale volatility is significant ${ }^{4}$, the goal is noncatastrophic oxidation behavior of the bare substrate alloy such that use of a protective coating is a reasonable protection approach (ie. local coating failure would not result in immediate component loss).

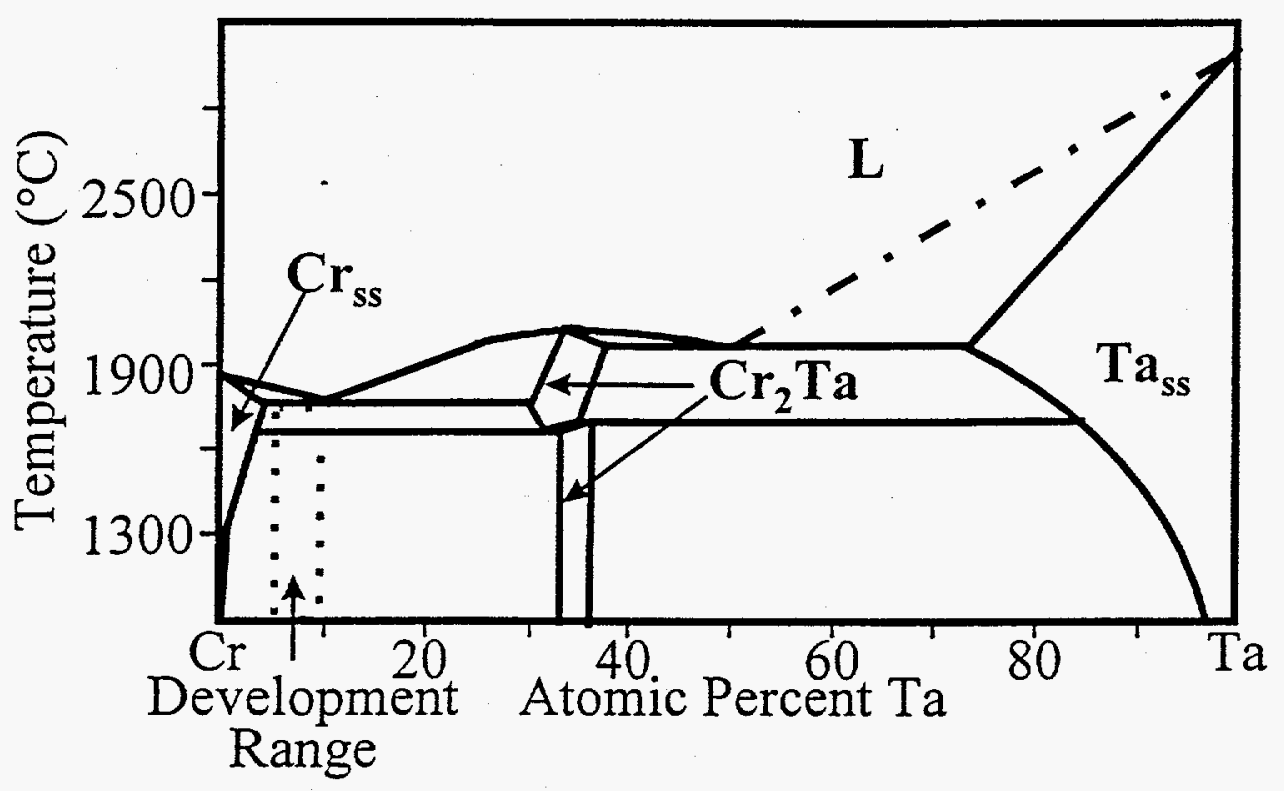

Fig. 1- Schematic binary $\mathrm{Cr}$-Ta phase diagram ${ }^{1,2}$.

\section{ALLOY PREPARATION AND PROCESSING}

Alloys based on the $\mathrm{Cr}-\mathrm{Cr}_{2} \mathrm{Ta}$ system weighing 400-500 g were prepared by arc melting and drop casting in a copper mold $\left(2.5 \mathrm{~cm}\right.$ diam $\times 7.6 \mathrm{~cm}$ long) preheated to $200^{\circ} \mathrm{C}\left(392^{\circ} \mathrm{F}\right)$. Small $40-60 \mathrm{~g}$ castings were also prepared by arc melting and drop casting in a chilled copper mold. High-purity chromium and other metal chips were used as charge materials. The alloys were easily cast and showed no evidence of cracking. After heat treatment, the larger $400-500 \mathrm{~g}$ alloy ingots were clad inside Mo billets and hot extruded at $1480^{\circ} \mathrm{C}\left(2696^{\circ} \mathrm{F}\right)$ and an extrusion ratio of $4: 1$. The hot-extruded material was then heat treated and used for tensile specimens. The small 40-60 g castings were used as-cast and/or after heat treatment to provide specimens for oxidation exposures and room temperature fracture toughness evaluation. The development range is based on $\mathrm{Cr}-(6-10) \mathrm{Ta}$ atomic percent, at.\% (Fig. 1). Detailed alloy compositions are not reported due to patent considerations, and are denoted in the report by the letter "X" followed by a number.

\section{ROOM TEMPERATURE FRACTURE TOUGHNESS}

Chevron notched three-point bend samples approximately $3 \mathrm{~mm} \times 4 \mathrm{~mm} \times(20-25) \mathrm{mm}$ were used to evaluate fracture toughness at room temperature. A modulus of $250 \mathrm{GPa}$ ( $36 \mathrm{ksi}$ ) was estimated for the $\mathrm{Cr}-\mathrm{Cr}_{2} \mathrm{Ta}$ based alloys. A modulus of $300 \mathrm{GPa}(43 \mathrm{ksi})$ was used for the $\mathrm{Cr}-(0-0.1 \times 10)$ alloys. Details of this technique are provided in ref. 5. 
Current $\mathrm{Cr}-\mathrm{Cr}_{2} \mathrm{Ta}$ based alloys have a room temperature fracture toughness in the 10-12 MPa $\sqrt{\mathrm{m}}$ range, with one alloy test sample exhibiting a toughness of $12.8 \mathrm{MPa} / \mathrm{m}$ (Table 1). This represents significant progress beyond the 7-8 MPa ${ }_{m}$ room temperature fracture toughness exhibited by the best $\mathrm{Cr}-\mathrm{Cr}_{2} \mathrm{Nb}$ based alloys previously developed under this initiative 6 . However, it is still short of the goal levels of 15-20 MPa $\sqrt{m}$.

Room temperature fracture toughness values of several binary $\mathrm{Cr}-\mathrm{Ta}$ and microalloyed $\mathrm{Cr}$ alloys are shown in Table 2. A comparison of Table 1 with Table 2 reveals that the alloy additions to the $\mathrm{C}_{\mathrm{T}}$ - $(8-$ 10)Ta base have not significantly increased room temperature fracture toughness. The binary $\mathrm{Cr}-(8-$ 10) Ta alloys exhibit room temperature fracture toughness values in the 9-10 $\mathrm{MPa} / \mathrm{m}$ range, only slightly below the 10-12 $\mathrm{MPa} \sqrt{\mathrm{m}}$ range achieved with further alloying. (It should be noted the alloying strategy adopted thus far has proven effective in improving high temperature strength and oxidation resistance).

Table 1- Room temperature fracture toughness of selected $\mathrm{Cr}-\mathrm{Cr}_{2} \mathrm{Ta}$ based alloys.

\begin{tabular}{|c|c|c|c|c|c|}
\hline $\begin{array}{l}\text { Alloy } \\
\text { No. }\end{array}$ & $\begin{array}{c}\text { Composition } \\
\text { (At.\%) }\end{array}$ & Microstructure & $\begin{array}{l}\text { Condition } \\
\text { and Heat } \\
\text { Treatment }\end{array}$ & \multicolumn{2}{|c|}{$\begin{array}{l}\text { Fracture Toughness } \\
(\mathrm{MPa} \sqrt{\mathrm{m}})\end{array}$} \\
\hline $\mathrm{CN144}$ & $\begin{array}{c}\mathrm{Cr}-8 \mathrm{Ta}-5 \times 1- \\
0.5 \times 3-0.011 \times 8\end{array}$ & Hypoeutectic & extruded, $1200^{\circ} \mathrm{C}$ & 11.0 & $11.0(1)$ \\
\hline & & & cast, $1000^{\circ} \mathrm{C}$ & 10.2 & $8.3(2)$ \\
\hline & & & cast, $1200^{\circ} \mathrm{C}$ & 8.3 & $7.9(2)$ \\
\hline $\mathrm{CN} 145$ & $\begin{array}{l}\mathrm{Cr}-10 \mathrm{Ta}-5 \times 1- \\
0.5 \times 3-0.011 \times 8\end{array}$ & Hypereutectic & cast, $1000^{\circ} \mathrm{C}$ & 8.7 & $6.0(2)$ \\
\hline & & & cast, $1200^{\circ} \mathrm{C}$ & 12.8 & $11.1(2)$ \\
\hline $\mathrm{CN} 147$ & $\begin{array}{l}\text { Cr-9.5Ta-5X1- } \\
0.5 \times 3-0.011 \times 8\end{array}$ & Eutectic & cast, $1200^{\circ} \mathrm{C}$ & 11.7 & $10.7(4)$ \\
\hline
\end{tabular}

Table 2- Room temperature fracture toughness of selected binary $\mathrm{Cr}$ - $\mathrm{Ta}$ and $\mathrm{Cr}$ alloys.

\begin{tabular}{|c|c|c|c|c|}
\hline $\begin{array}{c}\text { Composition } \\
(\text { At.\%) }\end{array}$ & Microstructure & $\begin{array}{c}\text { Condition } \\
\text { and Heat Treatment }\end{array}$ & $\begin{array}{c}\text { Fracture Toughness (MPa } \sqrt{m} \text { ) } \\
\text { Best }\end{array}$ \\
\hline \multicolumn{5}{|c|}{ Average (\# of tests) } \\
\hline $\mathrm{Cr}-8 \mathrm{Ta}$ & Hypoeutectic & cast, $1000^{\circ} \mathrm{C}$ & 10.4 & $9.8(3)$ \\
\hline $\mathrm{Cr}-11 \mathrm{Ta}$ & Hypereutectic & cast, $1000^{\circ} \mathrm{C}$ & 9.8 & $9.7(2)$ \\
\hline $\mathrm{Cr}-9.8 \mathrm{Ta}$ & $\approx$ Eutectic & cast, $1000^{\circ} \mathrm{C}$ & 9.0 & $9.4(2)$ \\
\hline \multicolumn{5}{|c|}{ Cr Matrix } \\
\hline $\mathrm{Pure} \mathrm{Cr}$ & $\mathrm{Cr}$ & cast, $1000^{\circ} \mathrm{C}$ & $\mathbf{1 6 . 1}$ & $\mathbf{1 5 . 2 ( 2 )}$ \\
\hline $\mathrm{Cr}-0.1 \mathrm{X} 10$ & & cast, $1000^{\circ} \mathrm{C}$ & $\mathbf{3 4}$ & $\mathbf{2 2 . 3 ( 3 )}$ \\
\hline
\end{tabular}

Alloying for further improvement in room temperature fracture toughness will focus on two key areas: the $\mathrm{Cr}_{\mathrm{SS}}$ phase and the $\mathrm{Cr}_{\mathrm{sS}}$ /Laves phase interface. Pure $\mathrm{Cr}$ containing $200 \mathrm{O}$ and $25 \mathrm{~N}$ weight parts per million, processed under similar conditions to the $\mathrm{Cr}-\mathrm{Cr}_{2} \mathrm{Ta}$ based alloys, exhibits a room temperature fracture toughness of $15-16 \mathrm{MPa} / \mathrm{m}$ (Table 2). Microalloying additions to improve the toughness of $\mathrm{Cr}$ are currently under evaluation. For example, the addition of 0.1 at. $\%$ of $X 10$ was recently found to increase the room temperature fracture toughness to level of $34 \mathrm{MPa} / \mathrm{m}$ in one test sample (Table 2). 
Manipulation of the $\mathrm{Cr}_{\mathrm{SS}}$ /Laves phase interface is the second route under consideration to further improve toughness. Understanding of processing/composition/microstructure relationships in the $\mathrm{Cr}$ - $\mathrm{Ta}$ system, including phase equilibria studies to determine the eutectic composition, has been achieved. Microstructures consisting of a fine dispersion of Laves particles in the $\mathrm{Cr}_{\text {sS }}$ matrix or lamellar $\mathrm{Cr}_{\text {ss }}$ /Laves eutectic structures can now be produced (Fig. 2). Very preliminary results suggest that the lamellar eutectic structures (Fig. 2a) may exhibit greater room temperature fracture toughness than the fine dispersed structures (Fig. 2b). Future work will concentrate on confirming and optimizing this effect through adjustments of microstructural parameters such as lamellar spacing and lamellar colony grain size.

a)

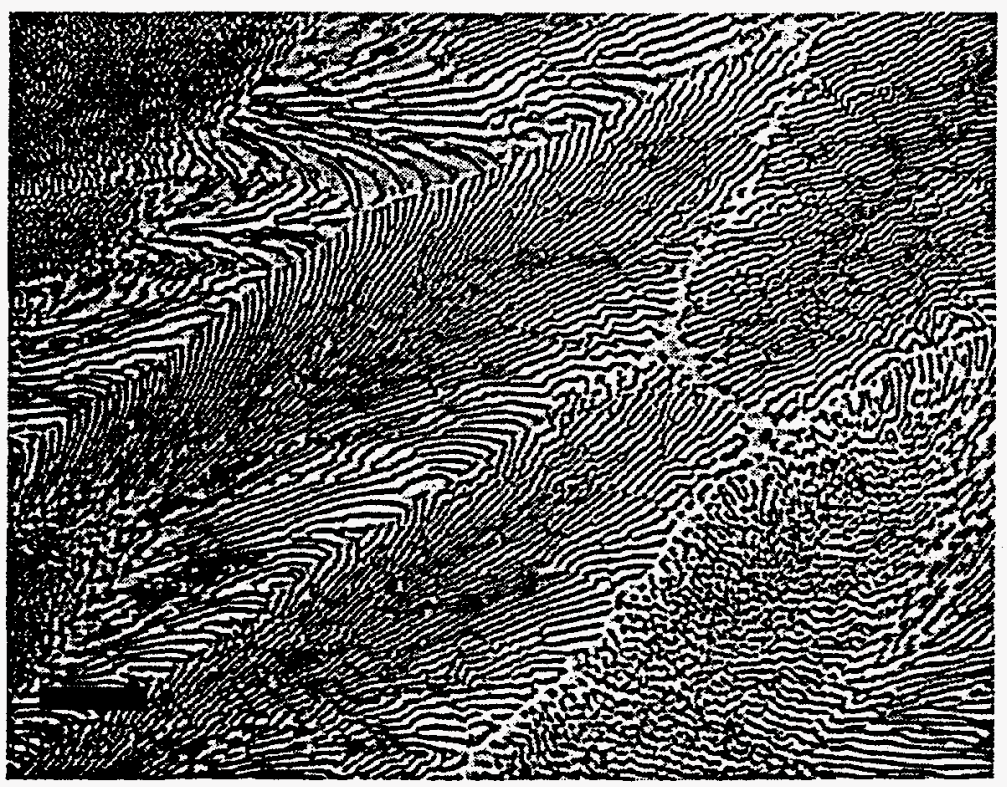

b)

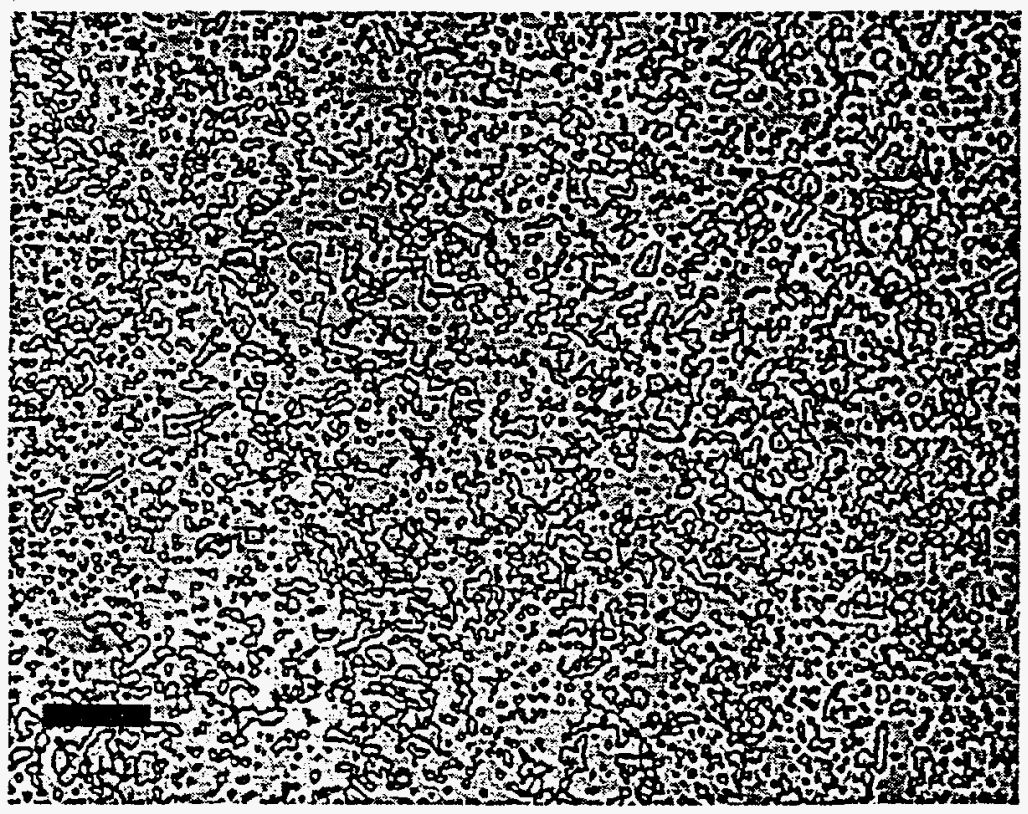

Fig. 2- Possible microstructures for $\mathrm{Cr}-\mathrm{Cr}_{2} \mathrm{Ta}$ based alloys (light microscopy). a) lamellar eutectic b) $\mathrm{Cr}_{2} \mathrm{Ta}$ Laves particles dispersed in a $\mathrm{Cr}_{\mathrm{ss}}$ matrix. 


\section{TENSILE PROPERTIES}

Button-type tensile specimens with gage dimensions $0.31 \mathrm{~cm}$ diam $\times 0.97-1.3 \mathrm{~cm}$ long were cut from hot-extruded material by electro-discharge machining, followed by grinding and polishing with " 0 " Emery paper. The specimens were tensile tested at room temperature and $800^{\circ} \mathrm{C}\left(1472^{\circ} \mathrm{F}\right)$ in air, and at $1200^{\circ} \mathrm{C}\left(2192^{\circ} \mathrm{F}\right)$ in vacuum (crosshead speed of approximately $0.25 \mathrm{~cm} /$ minute). Tensile properties are summarized in Tables 3-5.

At room temperature, no macroscopic yielding prior to fracture was observed. However, tensile fracture strengths in excess of $700 \mathrm{MPa}\left(100 \mathrm{ksi}\right.$ ) were achieved (Table 3). At $800^{\circ} \mathrm{C}$ in air, tensile elongations on the order of $1 \%$ were observed in several alloys, with yield strengths of around $900 \mathrm{MPa}(130 \mathrm{ksi})$ (Table 4). This suggests that the ductile to brittle transition temperature (DBTT) was just under $800^{\circ} \mathrm{C}$ $\left(1472^{\circ} \mathrm{F}\right)$. At $1200^{\circ} \mathrm{C}\left(2192^{\circ} \mathrm{F}\right)$, elongations were generally in the $20-30 \%$ range, with several alloys exhibiting tensile fracture strengths in excess of $345 \mathrm{MPa}(50 \mathrm{ksi})$ (Table 5). Thus, the $\mathrm{Cr}-\mathrm{Cr}_{2} \mathrm{Ta}$ based alloys meet the high temperature strength goals of the program.

Table 3-Room temperature tensile properties.

\begin{tabular}{|c|c|c|c|c|}
\hline $\begin{array}{c}\text { Alloy } \\
\text { No. }\end{array}$ & $\begin{array}{c}\text { Composition } \\
\text { Cr-8Ta-0.5X3 Base } \\
(\text { At.\%) }\end{array}$ & $\begin{array}{c}\text { Yield Strength } \\
\text { ksi (MPa) }\end{array}$ & $\begin{array}{c}\text { Fracture } \\
\text { Strength } \\
\mathrm{ksi}(\mathrm{MPa})\end{array}$ & $\begin{array}{c}\text { Elongation } \\
\%\end{array}$ \\
\hline $\mathrm{CN} 130$ & $5 \mathrm{X} 1$ & $>104(717)$ & $104(717)$ & $*$ \\
\hline $\mathrm{CN} 132$ & $5 \times 1-3 \times 2-.05 \times 6$ & $>71(489)$ & $71(489)$ & $*$ \\
\hline $\mathrm{CN} 133$ & $2.5 \times 1-3 \times 2$ & $>101(696)$ & $101(696)$ & ${ }^{*}$ \\
\hline $\mathrm{CN} 136$ & $6.5 \times 1-0.5 \times 6$ & $>87(600)$ & $87(600)$ & ${ }^{*}$ \\
\hline $\mathrm{CN} 137$ & $6.5 \times 1-0.05 \times 6-0.022 \times 8$ & $>92(634)$ & $92(634)$ & ${ }^{*}$ \\
\hline $\mathrm{CN} 144$ & $5 \times 1-0.011 \times 8$ & $>104(717)$ & $104(717)$ & ${ }^{*}$ \\
\hline $\mathrm{CN} 146$ & $8 \times 7-0.011 \times 8$ & $>80(552)$ & $80(552)$ & ${ }^{*}$ \\
\hline
\end{tabular}

*Fracture Prior to Macroscopic Yielding

Table $4-800^{\circ} \mathrm{C}\left(1472^{\circ} \mathrm{C}\right)$ tensile properties.

\begin{tabular}{|c|c|c|c|c|}
\hline $\begin{array}{c}\text { Alloy } \\
\text { No. }\end{array}$ & $\begin{array}{c}\text { Composition } \\
\text { Cr-8Ta-0.5X3 Base } \\
(\text { At. } \%)\end{array}$ & $\begin{array}{c}\text { Yield Strength } \\
\text { ksi (MPa) }\end{array}$ & $\begin{array}{c}\text { Fracture } \\
\text { Strength } \\
\text { ksi (MPa) }\end{array}$ & $\begin{array}{c}\text { Elongation } \\
\%\end{array}$ \\
\hline CN130 & $5 \times 1$ & $120(827)$ & $120(827)$ & 0.8 \\
\hline CN132 & $5 \times 1-3 \times 2-.05 \times 6$ & $134(924)$ & $137(944)$ & 1.2 \\
\hline CN133 & $2.5 \times 1-3 \times 2$ & $>69(476)$ & $69(476)$ & $*$ \\
\hline CN136 & $6.5 \times 1-0.5 \times 6$ & $>118(813)$ & $118(813)$ & $*$ \\
\hline CN137 & $6.5 \times 1-0.05 \times 6-0.022 \times 8$ & $128(882)$ & $131(903)$ & 0.9 \\
\hline CN144 & $5 \times 1-0.011 \times 8$ & $130(896)$ & $133(917)$ & 1.0 \\
\hline CN146 & $8 \times 7-0.011 \times 8$ & $>116(800)$ & $116(800)$ & $*$ \\
\hline
\end{tabular}

*Fracture Prior to Macroscopic Yielding 
Table $5-1200^{\circ} \mathrm{C}\left(2192^{\circ} \mathrm{F}\right)$ tensile properties.

\begin{tabular}{|c|c|c|c|c|}
\hline $\begin{array}{c}\text { Alloy } \\
\text { No. }\end{array}$ & $\begin{array}{c}\text { Composition } \\
\text { Cr-8Ta-0.5X3 Base } \\
(\text { At. } \%)\end{array}$ & $\begin{array}{c}\text { Yield Strength } \\
\text { ksi (MPa) }\end{array}$ & $\begin{array}{c}\text { Fracture Strength } \\
\text { ksi (MPa) }\end{array}$ & $\begin{array}{c}\text { Elongation } \\
\%\end{array}$ \\
\hline CN130 & $5 \times 1$ & $37(255)$ & $45(310)$ & 16.6 \\
\hline CN132 & $5 \times 1-3 \times 2-.05 \times 6$ & $42(290)$ & $51(352)$ & 18.5 \\
\hline CN133 & $2.5 \times 1-3 \times 2$ & $30(207)$ & $36(248)$ & 22.0 \\
\hline CN136 & $6.5 \times 1-0.5 \times 6$ & $46(317)$ & $56(386)$ & 14.3 \\
\hline CN137 & $6.5 \times 1-0.05 \times 6-0.022 \times 8$ & $37(255)$ & $45(310)$ & 28.1 \\
\hline CN144 & $5 \times 1-0.011 \times 8$ & $37(255)$ & $46(317)$ & 39.0 \\
\hline CN146 & $8 \times 7-0.011 \times 8$ & $30(206)$ & $36(248)$ & 25.8 \\
\hline
\end{tabular}

\section{HIGH TEMPERATURE OXIDATION}

The development effort focused on optimization of chromia scale growth kinetics of $\mathrm{Cr}-\mathrm{Cr}_{2} \mathrm{Ta}$ based alloys through microalloying, with an emphasis on reactive element (RE) additions. A series of alloys based on Cr-8Ta-5X1 with microalloying additions in the 0.05 to 1 at.\% range was selected for evaluation. Disk shaped oxidation specimens of $8-13 \mathrm{~mm}$ in diameter and $1 \mathrm{~mm}$ thickness were sectioned from as-cast and/or heat treated material and polished to a 600 grit finish using SiC paper. Evaluation of oxidation was performed by thermogravimetric analysis (TGA) at $950^{\circ} \mathrm{C}\left(1742^{\circ} \mathrm{F}\right)$ in dry air for $168 \mathrm{~h}$ and short term cyclic oxidation screening at $1100^{\circ} \mathrm{C}\left(2012^{\circ} \mathrm{F}\right)$. Screening tests at $1100^{\circ} \mathrm{C}\left(2012^{\circ} \mathrm{F}\right)$ were performed in a tube furnace open to room air. The samples were placed in a covered alumina crucible and inserted/removed from the furnace at temperature after intervals of $1,4,10,30,48$, and $120 \mathrm{~h}$ of cumulative exposure. Significant chromia volatility occurred as evidenced by green stains on the underside of the alumina crucible lid.

At $950^{\circ} \mathrm{C}\left(1742^{\circ} \mathrm{F}\right)$ in air, RE modified $\mathrm{Cr}-8 \mathrm{Ta}$ alloys exhibited a $2-7$ fold decrease in the rate of oxidation relative to binary $\mathrm{Cr}-8 \mathrm{Ta}$ (Fig. 3 ). No isothermal scale cracking was observed for the modified alloys during a $168 \mathrm{~h}$ isothermal exposure and the scale remained adherent on cooling. This behavior is in contrast to binary $\mathrm{Cr}-8 \mathrm{Ta}$, which exhibited a relatively low rate of oxidation but suffered from isothermal scale cracking and scale spallation on cooling to room temperature. The best RE modified $\mathrm{Cr}-8 \mathrm{Ta}$ based alloy oxidized at a rate within the range defined at the high end by Waspalloy, a commercial chromia-forming superalloy, and at the low end by MA754, a $\mathrm{Y}_{2} \mathrm{O}_{3}$ dispersed Ni-Cr alloy $\left(1000^{\circ} \mathrm{C}\right.$ data) which is among the most oxidation resistant chromia-forming alloys (Fig. 3 ). It should be noted that the oxidation kinetics of the RE modified $\mathrm{Cr}$-8Ta based alloys were not parabolic, although the rate of oxidation did decrease with time.

Microalloying additions were also successful at reducing the rate of oxidation at $1100^{\circ} \mathrm{C}\left(2012^{\circ} \mathrm{F}\right)$. The alloys generally exhibited a 3-5 fold decrease in the rate of oxidation and exhibited no scale spallation during the short term $1100^{\circ} \mathrm{C}\left(2012^{\circ} \mathrm{F}\right)$ cyclic oxidation screening test. The most recent $\mathrm{RE}$ modified $\mathrm{Cr}$ $8 \mathrm{Ta}$ based alloy exhibited a 50 fold decrease in the rate of oxidation as compared with $\mathrm{Cr}-8 \mathrm{Ta}-5 \mathrm{Xl}$ (Fig. 4), although it should be noted that this result has not yet been repeated. 


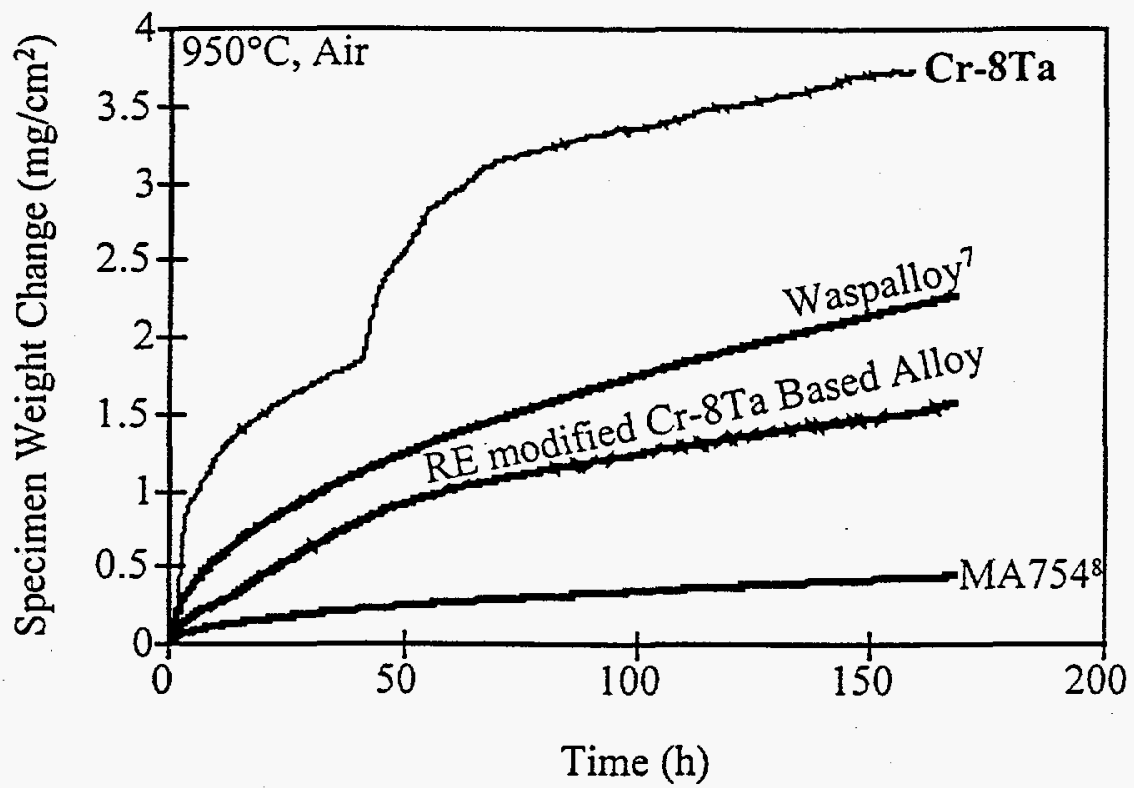

Fig. 3-TGA data at $950^{\circ} \mathrm{C}$ in dry air.

Overall, microalloying of the $\mathrm{Cr}-\mathrm{Cr}_{2} \mathrm{Ta}$ based alloys was successful in reducing the rate of oxidation and in improving scale adherence, although further compositional optimization is needed. Short term $(<200$ h) behavior was in the target goal range of chromia-forming oxidation kinetics below $900-1000^{\circ} \mathrm{C}(1652-$ $\left.1832^{\circ} \mathrm{F}\right)$ and noncatastrophic oxidation at $1100^{\circ} \mathrm{C}\left(2012^{\circ} \mathrm{F}\right)$. Although the behavior thus far is promising, longer term exposures ( $>1000 \mathrm{~h}$ ) are needed (and planned) before an assessment can be made of the oxidation performance of the microalloyed $\mathrm{Cr}-\mathrm{Cr}_{2} \mathrm{Ta}$ based alloys. Of particular concern is possible embrittlement from oxygen/nitrogen. Preliminary results suggest that the chromia scale formed on the $\mathrm{Cr}-\mathrm{Cr}_{2} \mathrm{Ta}$ based alloys can provide some protection from this type of embrittlement, but only if the scale remains adherent.

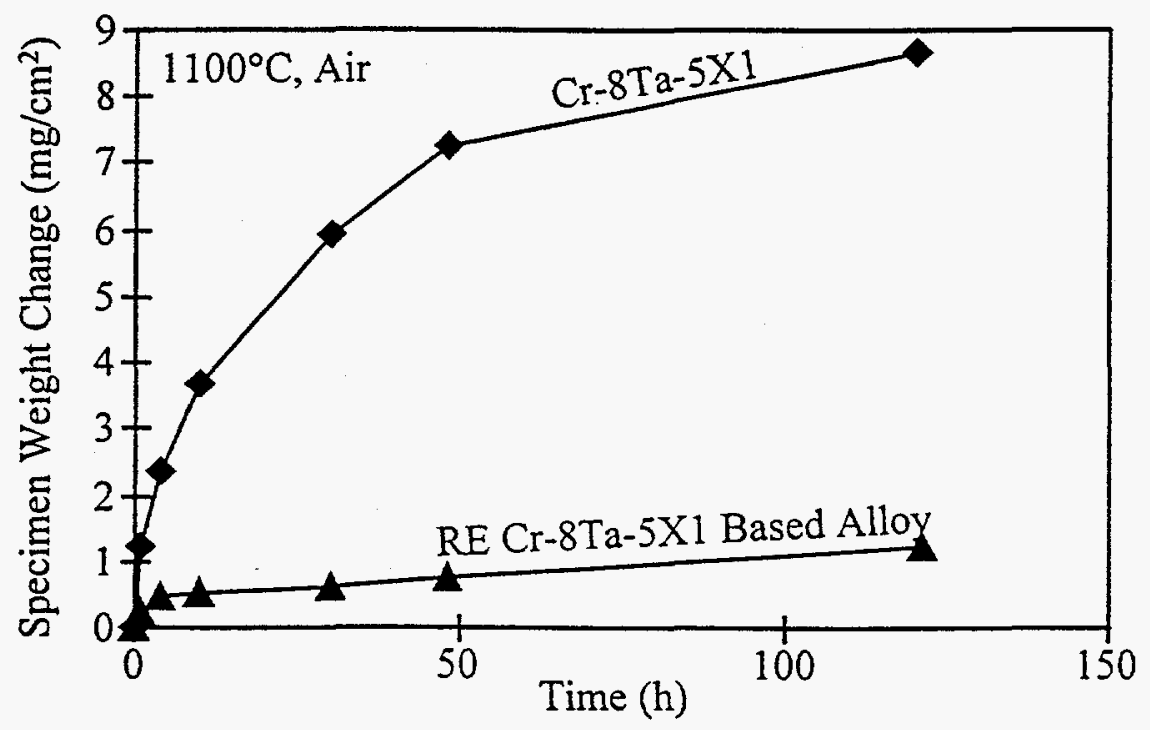

Fig. 4- Cyclic oxidation data at $1100^{\circ} \mathrm{C}$ in air. 


\section{SUMMARY AND FUTURE WORK}

The room temperature fracture toughness, high temperature strength, and oxidation resistance of a series of developmental $\mathrm{Cr}-\mathrm{Cr}_{2} \mathrm{Ta}$ based alloys were evaluated. The developmental goal of $345 \mathrm{MPa}(50 \mathrm{ksi})$ for tensile fracture strength at $1200^{\circ} \mathrm{C}\left(2192^{\circ} \mathrm{F}\right)$ was met. Significant improvement in room temperature fracture toughness over previously developed $\mathrm{Cr}-\mathrm{Cr}_{2} \mathrm{Nb}$ based alloys was achieved, with the $\mathrm{Cr}-\mathrm{Cr}_{2} \mathrm{Ta}$ based alloys exhibiting toughness in the $10-12 \mathrm{MPa} \sqrt{m}$ range as compared with $7-8 \mathrm{MPa} \sqrt{m}$ for $\mathrm{Cr}$ $\mathrm{Cr}_{2} \mathrm{Nb}$. Although short of the goal of $15-20 \mathrm{MPa} / \mathrm{m}$, further improvements are thought possible through microalloying of the $\mathrm{Cr}_{\text {ss }}$ phase and manipulation of the $\mathrm{Cr}_{\text {SS }}$ /Laves phase interface. Microalloying with reactive elements successfully reduced the rate of chromia scale formation during short term $950^{\circ} \mathrm{C}$ $\left(1742^{\circ} \mathrm{F}\right)$ and $1100^{\circ} \mathrm{C}\left(2012^{\circ} \mathrm{F}\right)$ exposures in air. Long-term oxidation studies and optimization of microalloying levels are planned.

\section{REFERENCES}

1. M. Venkatraman and J.P. Neumann, in Binary Alloy Phase Diagrams, Vol. 1, T.B. Massalaski, J.L. Murray, L.H. Bennett, and H. Baker eds., ASM, p. 867 (1986).

2. J.H. Zhu and C.T. Liu, unpublished research (1997).

3. M.P. Brady, J.H. Zhu, C.T.Liu, P.F. Tortorelli, J.L. Wright, C.A. Carmichael, and L. R. Walker, in Proc. of the Eleventh Annual Conference on Fossil Energy Materials, R.R. Judkins (comp.), U. S. Department of Energy, p. 195 (December 1997).

4. P. Kofstad, High-Temperature Corrosion, Elsevier, London, 1988.

5. J.H. Schneibel, C.A. Carmichael, E.D. Specht, and R. Subramanian, Intermetallics, 5, p. 61 (1997).

6. C. T. Liu, P. F. Tortorelli, J. A. Horton, D. S. Easton, J. H. Schneibel, L. Heatherly, C. A Carmichael, M. Howell, and J. L. Wright, in Proc. Ninth Annual Conf. Fossil Energy Materials, N. C. Cole and R. R. Judkins (comp.), U. S. Department of Energy, p. 415 (August 1995).

7. J.H. Chen, P.M. Rogers, and J.A. Little, Oxidation of Metals, Nos. 5/6, p. 381 (1997).

8. B.A. Pint and L. Hobbs, unpublished research (1990).

\section{ACKNOWLEDGEMENTS}

The authors thank Dewey Easton for the hot extrusions, and Jim Distefano, Lee Pike, and Ian for their reviews of the manuscript. This research was sponsored by the Fossil Energy Advanced Research and Technology Development (AR\&TD) Materials Program, U S. Department of Energy, under contract DE-AC05-96OR22464 with Lockheed Martin Energy Research Corporation. 